\title{
Measurements of the Marine Reservoir Effect on Radiocarbon Ages in the Eastern Bering Sea
}

\author{
DON E. DUMOND ${ }^{1}$ and DENNIS G. GRIFFIN ${ }^{2}$
}

(Received 27 February 2001; accepted in revised form 23 July 2001)

\begin{abstract}
The marine reservoir effect is known to skew radiocarbon dating (marine samples appear "older" than terrestrial samples of equivalent age), but the magnitude of this effect is not the same in all locations. Carbon-14 age determinations from 23 paired samples of terrestrial and marine origin are presented for five areas around the northern and eastern Bering Sea. It appears statistically suitable to average the age differences for three pairs, weighted inversely by variance. Differences from within each of 14 pairs of wood charcoal vs. sea mammal residue (from St. Lawrence Island, Cape Prince of Wales, Nunivak Island, Alaska Peninsula, and Unalaska Island) yield a weighted mean of $737 \pm 20$ years. Somewhat more variant differences from within each of five additional pairs of wood charcoal vs. sea mammal residue (St. Lawrence Island, Unalaska Island) provide a lower weighted mean of $460 \pm 41$ years. Differences from within each of four pairs of wood charcoal vs. marine shell (Nunivak Island) produce a weighted mean of $459 \pm 32$ years. Variations in these apparent reservoir effects presumably result largely from the interplay of differential ocean water upwelling and customary faunal feeding areas, although possible effects of other species characteristics cannot be ruled out. Dating of marine samples from the Bering Sea should thus either proceed with the expectation that age determinations may not be accurate within several centuries, or be approached through experimental measurement of reservoir effect among restricted faunal species in limited areas. Overall, the effect throughout the eastern Bering Sea appears to range from about 450 to 750 years.
\end{abstract}

Key words: Alaska, Bering Sea, reservoir effect, radiocarbon, differential ages, archaeology, shell, marine mammal

RÉSUMÉ. On sait que l'effet du réservoir marin biaise la datation au radiocarbone (les échantillons marins semblent être «plus vieux» que les échantillons terrestres d'âge similaire), mais la grandeur de cet effet n'est pas la même à tous les endroits. On présente les déterminations de l'âge au carbone 14 pour 23 échantillons appariés d'origine terrestre et marine provenant de cinq zones situées aux environs de la mer de Béring septentrionale et orientale. Il semble approprié sur le plan statistique d'établir la moyenne des différences d'âge pour trois paires, pondérées inversement par la variance. Les différences provenant de chacune des 14 paires de charbon de bois comparé à des restes de mammifère marin (île Saint-Laurent, cap Prince-de-Galles, île Nunivak, péninsule d'Alaska, et île Unalaska) donnent une moyenne pondérée de $737 \pm 20$ ans. Des différences un peu plus variables provenant de chacune de cinq autres paires de charbon de bois comparé à des restes de mammifère marin (île Saint-Laurent, île Unalaska) donnent une moyenne pondérée plus faible de $460 \pm 41$ ans. Les différences entre chacune des quatre paires de charbon de bois comparé à des coquillages marins (île Nunivak) donnent une moyenne pondérée de $459 \pm 32$ ans. Les variations dans ces effets de réservoir apparents proviennent probablement en grande partie du jeu réciproque entre les zones de remontée différentielle des eaux océaniques et les aires d'alimentation habituelles, bien qu'on ne puisse éliminer les effets possibles de caractéristiques propres à d'autres espèces. La datation des échantillons marins de la mer de Béring devrait donc se faire soit en s'attendant à des erreurs de plusieurs siècles dans les déterminations d'âge, soit en l'abordant par le biais de mesures expérimentales portant sur l'effet de réservoir parmi un petit nombre d'espèces fauniques et à l'intérieur d'un territoire restreint. Dans l'ensemble, cet effet dans tout l'est de la mer de Béring semble aller de 450 à 750 ans.

Mots clés: Alaska, mer de Béring, effet de réservoir, radiocarbone, âges différentiels, archéologie, coquillage, mammifère marin

Traduit pour la revue Arctic par Nésida Loyer.

\section{INTRODUCTION}

It is now well known that radiocarbon dating of marine samples—-shell or marine mammal residue—is skewed by the reservoir effect of the oceans, so that in most regions marine samples yield radiocarbon ages substantially older than those yielded by terrestrial samples that are in fact equivalent in true calendar age. Although data regarding magnitude and regional variations of this effect have been presented for a number of regions of the world, no presentation has specifically targeted the Bering Sea. Here, we present suites of archaeologically derived dates on paired samples of terrestrial and marine origin from five areas in and around the northern and eastern Bering Sea. The St.

\footnotetext{
${ }^{1}$ Department of Anthropology, 1218 University of Oregon, Eugene, Oregon 97403, U.S.A.; ddumond@ oregon.uoregon.edu

${ }^{2}$ Archaeological Frontiers, 295 East 33rd Ave., Eugene, Oregon 97405, U.S.A.

(C) The Arctic Institute of North America
} 
Lawrence Island dates are based on samples collected nearly three-quarters of a century ago but dated recently, and we also consider some ages obtained there in the 1970s. Excavation dates of samples from four other locations were as follows: Nunivak Island, 1996 and 1997; lower Naknek River on Bristol Bay, 1998; Cape Prince of Wales, 1998 and 1999; Umnak Island of the eastern Aleutians, 1998.

Archaeologists working in the North first became aware of the problem of determining site age on the basis of marine products some 25 years ago, when it was pointed out that ages from seal products systematically "predated" those obtained from wood charcoal samples in apparently contemporary contexts (e.g., McGhee and Tuck, 1976). Since that time, a number of studies have presented information bearing on the question, with some particular attention paid to the dating of marine shells collected on dates known historically (e.g., Robinson and Thompson, 1981). We are aware of only one previous attempt with shellfish from the Bering Sea, involving shell of Astarte borealis dredged live in 1969 from a spot $50 \mathrm{~km}$ or so south-southwest of Cape Prince of Wales, which in 1974 yielded the relatively imprecise (and unpublished) radiocarbon age of $540 \pm 200$ years (sample W-2768; R. Rowland, pers. comm. 1999).

Stated briefly, atmospheric ${ }^{14} \mathrm{C}$ results from cosmic bombardment, the magnitude of which varies in response to short-term fluctuations in the strength of magnetic fields, both terrestrial and interplanetary. Although the worldwide level of radioactive carbon that results and enters into atmospheric carbon dioxide is roughly constant at any given time, the speed and degree of exchange with the ocean are influenced by water depth, so that radiocarbon measurements tend to vary inversely with distance from surface. Materials from surface waters-the upper $75-199 \mathrm{~m}$ - measure on worldwide average about 400 years too "old" compared to terrestrial samples, whereas those from greater depths measure correspondingly "older" (Oeschger et al., 1975; Stuiver and Braziunas, 1993). At the same time, however, the effect in the various levels of the ocean is to dampen reflections of short-term oscillations that occur in the incidence of atmospheric ${ }^{14} \mathrm{C}$ (see, for instance, Stuiver and Braziunas, 1993: Fig. 14).

This phenomenon constitutes the oceanic reservoir effect. But it has been clearly shown that substantial regional variation in the magnitude of this effect in surface waters results from the degree of local upwelling, which brings deeper waters into the upper levels (Taylor, 1987:126131; Bowman, 1990:24-25; Stuiver and Braziunas, 1993). In this connection, all waters entering the Bering Sea proceed from the Alaska Current that moves counterclockwise around the Gulf of Alaska, flowing southwestward over (and possibly through) the deep Aleutian Trench, from which some waters turn north through various channels between the Aleutian Islands. After circling counterclockwise in the Bering Sea, especially southwest of the edge of the Bering Platform, where some depths exceed $3000 \mathrm{~m}$, a portion of these waters exits between the westernmost Aleutians and the Kamchatka Peninsula, whereas other portions flow more steadily northward above the Bering Platform and through Bering Strait into the Chukchi Sea (U.S. Department of Commerce, 1961).

One of the major discussions of the reservoir problem, oriented toward achieving a means for reconciling marinebased determinations not only with those from terrestrial samples, but also with the modern calendar (Stuiver and Braziunas, 1993), recognizes the existence of worldwide variations in the reservoir effect. However, it proposes an overall model of the effect in the surface layers of the ocean that mitigates the impact of short-term fluctuations in atmospheric ${ }^{14} \mathrm{C}$ by attempting to parallel the damping effect of the ocean on such fluctuations in the atmosphere. A computer program (CALIB) incorporates the model into a calendrical calibration routine (Stuiver and Reimer, 1993). Using the model, in which the overall effect is to reduce ${ }^{14} \mathrm{C}$ ages on marine samples by a general correction (or $\Delta \mathrm{R}$ ) of about 400 years, individual corrections must be introduced to modulate the magnitude of the effect for specific regions.

When the model is considered for use in certain archaeological situations, one problem is that it is based on determinations from shell rather than from marine vertebrates, and it assumes known calendar dates for collection of the shell on which regional modifications to the overall effect are based. That is, a shell collected on a known date yields a ${ }^{14} \mathrm{C}$ age indicative of a date $\mathrm{X}$ number of years earlier (or occasionally later) than the calendar date. This error period or "reservoir age" is then compared to the age offset modeled for that calendar date in the overall system (Stuiver and Braziunas, 1993: Fig. 17 and Table 1). The difference between the two (i.e., between the reservoir age and the modeled age offset) forms the local correction to $\Delta \mathrm{R}$ that is entered into the calibration program.

However, one may wish to derive such a correction from a comparison of prehistoric samples of, say, wood charcoal on the one hand and a marine product (such as walrus ivory) on the other. In this case, one has a base terrestrial "date" expressed as an age in ${ }^{14} \mathrm{C}$ years that is less than absolutely precise-that is, it is accompanied by a stated standard error as estimate of variance. This base date must then be calibrated in order to provide the requisite calendar date, a process that introduces an additional finite variance. Next, this substantially expanded date or age span must be deducted from the radiocarbon-indicated age of the marine samples, which further expands the variance of the interval because of the stated variance in the marine sample age that is given by the laboratory. It is thus this greatly expanded interval that must be reconciled with the modeled overall marine $\Delta \mathrm{R}$ (which is also shown with a slight variance estimate), expanding the variance still further. Yet this is the quantity to be entered into the computer program to lead to a presumably usable calibration of the date of the marine sample-a calibration that now carries such a wide estimate of variance as essentially to cancel any advantage of use of the oceanic model in avoiding short-term atmospheric fluctuations in ${ }^{14} \mathrm{C}$. To 
avoid this problem, Stuiver and Braziunas (1993:152 153) suggest that one can use their plot of atmospheric radiocarbon age against their modeled marine radiocarbon age (Stuiver and Braziunas, 1993: Fig. 15) to convert a measured terrestrial age to a model marine age, which can then be compared directly with a measured marine age to obtain the correction value. Our present intent, however, is simply to provide information bearing on the gross variations between marine and terrestrial radiocarbon ages as measured directly.

A second problem in using the model derives from reports that the worldwide model of Stuiver and Braziunas makes the carbon budget of the upper level of the oceans more uniform than it is. As will be indicated, a spurious uniformity may be the case, especially with regard to determinations on marine shell. A number of reports present evidence from restricted areas in which marine shell determinations among themselves vary far more in their differences from terrestrial dates and from each other than uniformitarian expectations would hold (e.g., Taylor, 1987:130-131; Dye, 1994; Ingram and Southon, 1996; Kennet et al., 1997). Not only this, but among the data that Stuiver and Braziunas (1993) amassed to provide the basis of their formulation, at least some involved means of "reservoir ages" far too divergent from one another to be acceptably averaged according to standard statistical reasoning. For example, seven reservoir ages ranging from 700 \pm 50 to $915 \pm 30$ years are averaged to provide a mean value supposedly suitable for use on the Northwest Coast (Robinson and Thompson, 1981; Stuiver and Braziunas, 1993), but analysis of variance suggests that the seven reservoir ages could not under any stretch of reasonable imagination be considered to represent a single difference value (i.e., $F=14.59$, with d.f. 6 and $\infty$ ). Other researchers (e.g., Ingram and Southon, 1996) appear to have made use of the same procedure, which we believe to be questionable.

Finally, there is reason to question whether age determinations from marine shell and those from marine vertebrates manifest the same magnitude of departure from determinations derived from terrestrial organisms (e.g., Dyke et al., 1996; Ingram and Southon, 1996). As we show here, samples from Nunivak Island appear to demonstrate a significant difference in this respect, with determinations from shell slightly closer to those from terrestrial materials, although substantially more variant. In the concluding section, we present a possible explanation for the major discrepancy that does not depend simply on postulated organic differences between species in their absorption of ${ }^{14} \mathrm{C}$.

\section{THE PRESENT DATA}

\section{St. Lawrence Island}

In 1930 and 1931, crews under the direction of Henry B. Collins, Jr., of the Smithsonian Institution excavated a series of sites in the immediate vicinity of Gambell, at the northwest corner of St. Lawrence Island. In what he considered the oldest of the sites, which he termed Hillside, Collins excavated in two house ruins, which he described in his report of excavations (Collins, 1937). These house ruins were dated at $1634 \pm 127$ radiocarbon years ago (House 1, P-95; Rainey and Ralph, 1959) and $1413 \pm 240$ and $1422 \pm 140$ years ago (House 2, P-70 and P-94; Rainey and Ralph, 1959). But these dates on Houses 1 and 2 were made questionable because of still earlier dates obtained on some other Gambell sites that Collins (1937), with considerable reason, had argued to be later than his Hillside site.

In 1995, while reanalyzing the Collins Hillside site collections at the National Museum of Natural History, one of us (Dumond) found that wads of grassy plants had been recovered from frozen deposits between and below the floor stones of both House 1 and House 2 (Dumond, 1998). The material was found stored in trays in standard museum cases; the original field treatment of the material was unfortunately not recorded, but the now-desiccated vegetation showed no visible sign of mildew or other deterioration. With permission from the museum's Department of Anthropology, a $5 \mathrm{gm}$ portion of each sample that appeared visually to be representative of the whole was chosen for dating by the AMS method. These samples yielded "conventional" radiocarbon age determinations (i.e., those corrected for isotopic fractionation by adjusting $\delta^{13} \mathrm{C}$ to -25.00 , as are all of the carbon ages used here), of $1770 \pm 40$ (House 1; Beta-93160) and $1680 \pm 40$ years (House 2; Beta-93159). Although these two are close enough to each other to suggest a temporal overlap, determinations from a single entity can be expected to exhibit such a spread only little more than $5 \%$ of the time $(t=1.59)$. We therefore refrain from averaging the two.

Later, with a view toward gaining information regarding the magnitude of the reservoir effect in the Bering Sea, Dumond approached the National Museum of Natural History for permission to date samples of ivory from as nearly as possible the same excavation units as those yielding the grass samples-that is, from the floor areas of the houses, as recorded in 1930. Samples chosen were unmodified fragments of recognizable tusks, apparently waste or unused raw material, that in color and state of preservation appeared representative of the plentiful ivory recovered from the two houses, each of which is assumed to have been occupied for no more than a generation. In early 1998, results were obtained from the AMS dating of two separate samples from each house. These are set out together with the grass samples in Table 1.

Clearly, within each of the house units, the two walrus ivory ages are close enough that they can reasonably be averaged, with spreads in magnitude such as would occur about $10 \%$ of the time. But between the two houses, the grass-ivory differences, 720 and 514 years, are too far apart to be accepted on statistical grounds as reflecting a single underlying value. 
TABLE 1. Paired ${ }^{14} \mathrm{C}$ ages of ivory and grass from the Hillside Site (XSL001), St. Lawrence Island.

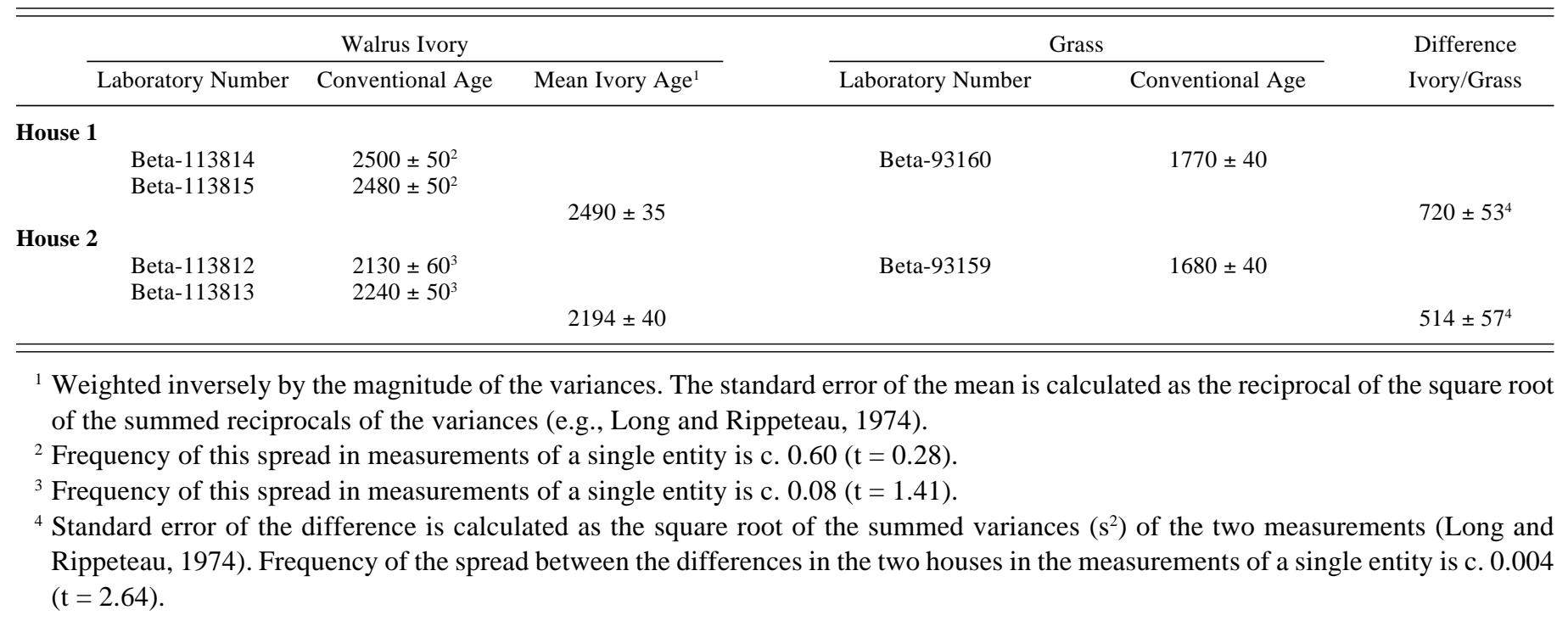

Which of these values is to be chosen, or do both accurately reflect sea-mammal age measured from samples contemporary with the grass? The latter answer may be suggested from a set of paired ${ }^{14} \mathrm{C}$ determinations reported from graves in the Gambell area by H.-G. Bandi (1984:61), each pair consisting of a date on wood and another on whale bone (species undetermined) from a single grave (Table 2). Bandi concluded that both the whale remains and the wood fragments (from burial offerings or stakes apparently integral to the graves) had been positioned in the graves at the time of burial.

As indicated in Table 2, analysis of variance suggests that there is less than a $5 \%$ chance that the separate age differences of the six burial pairs are manifestations of a single underlying value. Such variation as reflected could result from the existence of underlying variation in the marine reservoir effect, as through variation in the ocean areas in which the whales (possibly of different species) had commonly fed. But it could also be owed to factors such as the presence of old driftwood (frozen for years on the beach?) in some of the graves-for with no native trees on St. Lawrence Island, wood of any size must be considered of drift origin. Whatever the cause, given the nature of radiocarbon measurements and the spans by which ages are reported, as well as the real probability that at least some overlapping spans indicate more limited underlying values, it is reasonable to convert the set of six differences into smaller sets, each of which can promise the possibility of reflecting an underlying uniformity.

In Table 2, the original set is segmented. Although the differences in the entries numbered 1,3, 4, and 6-the four largest of the original set-may relate to a single value, such a spread would be manifest less than $10 \%$ of the time; the weighted mean is $651 \pm 60$. Much stronger sets are obtained by separating items 1,4 , and 6 from 2,3 , and 5 (Table 2, probabilities shown). The first of these subsets provides a weighted mean of $690 \pm 66$; the second, of
$383 \pm 77$. It is tempting to relate the first subset to the marine effect, and the second either to wood that was old at the time it was placed in the burial, or else to remains of whales of different feeding patterns-an explanation of potentially greater long-range explanatory power.

Indeed, the two separate values obtained from comparisons of walrus ivory and grass determinations from houses 1 and 2 at the Hillside site may well indicate that there is variation in the marine reservoir effect manifest in animals taken in the same waters, possibly as a result of variation in the feeding patterns. For example, the Pacific bowhead whale (Balaena mysticetus), a surface feeder that largely restricts itself to the Bering Sea and immediately adjacent areas, has reportedly been the favored prey in the recent past. However, there is evidence that St. Lawrence Island people, as well as their relatives on the nearby Siberian mainland, have also taken a significant number of young gray whales (Eschrichtius robustus), migratory benthic feeders that may do at least a small part of their feeding in the Pacific, well south of the Bering Sea (Hughes, 1960:111-112; Krupnik, 1993:76). On the other hand, that the variation in differences from the graves is not a reflection of some overall and regular secular change in the reservoir effect, is suggested strongly by rank order correlations between marine-terrestrial differences and the ages of the terrestrial (wood) samples (Table 2, notes).

Either of the larger means (whale bones vs. wood) obtained from the burial subsets $-690 \pm 66$, or $651 \pm 60$ is close enough to the difference of $720 \pm 53$ calculated from House 1 (on ivory vs. grass) that it could reflect the same underlying value, with such spreads likely to occur nearly $40 \%$ or $20 \%$ of the time, respectively $(t=0.31,0.9)$. Both thus serve to support the conclusion that the $720 \pm 53$ value from House 1 is within reason.

Similarly, the differences $514 \pm 57$ (ivory vs. grass) from House 2 and $383 \pm 77$ (whale bone vs. wood) from 
TABLE 2. Paired ${ }^{14} \mathrm{C}$ ages of whale bone and wood from Gambell burials ${ }^{1}$.

\begin{tabular}{|c|c|c|c|c|c|}
\hline \multirow[b]{2}{*}{ Burial } & \multicolumn{2}{|c|}{ Whale Bone $(\delta 13 \mathrm{C}=-13.3 \pm 2)^{2}$} & \multicolumn{2}{|c|}{ Wood $(\delta 13 C=-25.0 \pm 2)$} & \multirow{2}{*}{$\begin{array}{l}\text { Difference }^{4} \\
\text { Bone/Wood }\end{array}$} \\
\hline & Laboratory Number & Conventional $\mathrm{Age}^{3}$ & Laboratory Number & Conventional $\mathrm{Age}^{3}$ & \\
\hline 1. G42/1 & B-2853 & $1948 \pm 78$ & B-2852 & $1270 \pm 86$ & $678 \pm 114$ \\
\hline 2. G102 & B-2875 & $1908 \pm 78$ & B-2859 & $1530 \pm 94$ & $378 \pm 122$ \\
\hline 3. G24 & B-2440 & $1588 \pm 108$ & B-2434 & $1100 \pm 86$ & $488 \pm 138$ \\
\hline 4. G16 & B-2870 & $1528 \pm 84$ & B-2862 & $940 \pm 78$ & $588 \pm 115$ \\
\hline 5. G50 & B-2857 & $1298 \pm 84$ & B-2858 & $990 \pm 86$ & $308 \pm 120$ \\
\hline 6. G11 & B-2433 & $1288 \pm 92$ & B-3204 & $460 \pm 86$ & $828 \pm 126$ \\
\hline
\end{tabular}

Comparison of variances within and between conventional ages:

1-6: Frequency of spread in measurements of a single entity, $<0.05$ ( $F=2.3,5 / \infty$ d.f.)

1, 3, 4, 6: Frequency of spread in measurements of a single entity, $<0.1$ ( $\mathrm{F}=1.9,3 / \infty$ d.f. $)$

1, 4, 6: Frequency of spread in measurements of a single entity, $>0.9$ ( $F=0.55,2 / \infty$ d.f. $)$

2, 3, 5: Frequency of spread in measurements of a single entity, $>0.9(\mathrm{~F}=0.48,2 / \infty$ d.f. $)$

Mean of differences, weighted inversely by variances ${ }^{5}$

$1-6=547 \pm 50.1,3,4,6=651 \pm 60.1,4,6=690 \pm 66.2,3,5=383 \pm 77$.

Rank order correlations: Whale bone determinations vs. within-pair differences: rho = -.086. Wood determinations vs. within-pair differences: rho $=-.43$.

${ }^{1}$ From Bandi (1984:61), with uncalibrated BC/AD dates converted to radiocarbon years before 1950.

${ }^{2}$ Species not reported.

${ }^{3}$ Conventional ages here include an added 50 years' variance (see Clark, 1975), as well as the adjustment necessary to bring the estimated $\delta 13 \mathrm{C}$ of the whale bone to $-25.00 \%$ o.

${ }^{4}$ Standard error of the difference is calculated as the square root of the summed variances of the two measurements (Long and Rippeteau, 1974).

${ }^{5}$ Standard error of mean difference is calculated as the reciprocal of the square root of the summed reciprocals of variances of the individual differences (Long and Rippeteau, 1974).

graves are no more spread than might be expected about $10 \%$ of the time in two determinations of the same entity $(t=1.31)$, although the possibility certainly remains of the presence of older wood in those graves. Dyke et al. (1996, with additional references) minimize the problem of old wood, pointing out (among other things) that wood not locked in ice will remain buoyant for less than two years. Thus, whereas the use of driftwood may not be problematic enough to eliminate its use for dating, the possibility remains in the North that wood found in sites in treeless areas had been frozen in along the shores for some years before collected, or that such wood consists of only the inner rings of what were once larger tree trunks.

\section{Nunivak Island}

In 1996 and 1997, one of us (Griffin) conducted a program of excavations at the prehistoric and historic site of Nash Harbor (site XNI003) on Nunivak Island, in which a number of $10 \mathrm{~cm}$ thick excavation units produced datable charcoal (presumably from driftwood), marine mammal remains, and shell of mussels (Mytilus edulis) in various combinations (Griffin, 1999). The appropriate sample pairs are set out in Table 3 .

Of these, the charcoal sample from pit 7 , level 7 , is clearly aberrant. Although the direct comparison of seal bone and mussel shell from that level is comparable to other such comparisons, those involving charcoal from that unit with both mussel shell and sea-mammal residue are far outside the values given by all other pairs in each category, presumably as the result of a misunderstanding during excavation of the stratigraphic position of the charcoal. We therefore reject those comparisons that include charcoal from pit 7, level 7. Once this is done, the remaining determinations provide more coherent results. This is especially the case with walrus ivory or seal bone compared with charcoal, in which the differences within all pairs are extremely close-as close as would be expected in about three-quarters of cases involving this many samples - and yield a mean value of $771 \pm 29$ years for the differences of the total set. The spread of the differences between mammal parts and mussel shell, however, would be expected little more than $5 \%$ of the time, whereas that of the differences between mussel shell and charcoal would be expected even less than $5 \%$ of the time.

We suggest that these results do reflect some greater variability in marine shell dates, as mentioned at the outset. Indeed, the variation is great enough that, on statistical grounds, the marine shell-charcoal differences, in particular, should probably not be averaged. We do so here only as an illustration of the apparent magnitude of the different results to be obtained from mollusk shells and sea mammal residue. It is abundantly clear from these comparisons that it would be unwise on the basis of shell determinations such as these to define a Bering Sea reservoir effect that would then be used to correct determinations from sea mammal residue. 
TABLE 3. Paired ${ }^{14} \mathrm{C}$ ages of marine materials and wood charcoal, Nash Harbor (XNIO03).

\begin{tabular}{|c|c|c|c|c|c|c|c|}
\hline \multirow[b]{2}{*}{$\begin{array}{l}\text { Provenience } \\
\text { Pit/Level }\end{array}$} & \multicolumn{3}{|c|}{ Sample 1} & \multicolumn{3}{|c|}{ Sample 2} & \multirow[b]{2}{*}{ Difference $^{1}$} \\
\hline & $\begin{array}{l}\text { Laboratory } \\
\text { Number }\end{array}$ & Material & $\begin{array}{c}\text { Conventional } \\
\text { Age }\end{array}$ & $\begin{array}{l}\text { Laboratory } \\
\text { Number }\end{array}$ & Material & $\begin{array}{c}\text { Conventional } \\
\text { Age }\end{array}$ & \\
\hline \multicolumn{8}{|c|}{ Marine Mammal - Charcoal Comparisons } \\
\hline $1 / 5$ & AA26526 & walrus ivory & $1200 \pm 50$ & AA23664 & charcoal & $455 \pm 45$ & $745 \pm 67$ \\
\hline $1 / 12$ & AA26527 & seal bone $e^{2}$ & $1230 \pm 50$ & AA23665 & charcoal & $460 \pm 50$ & $830 \pm 71$ \\
\hline $2 / 3$ & AA26529 & walrus ivory & $965 \pm 50$ & AA26528 & charcoal & $205 \pm 40$ & $760 \pm 64$ \\
\hline $3 / 5,6$ & AA26531 & walrus ivory & $1170 \pm 50$ & AA26530 & charcoal & $335 \pm 40$ & $835 \pm 64$ \\
\hline $4 / 25-7$ & AA26533 & walrus tooth & $1075 \pm 50$ & Beta-100069 & charcoal & $370 \pm 40$ & $705 \pm 64$ \\
\hline & AA26534 & seal bone $^{2}$ & $1165 \pm 50$ & AA26535 & charcoal & $950 \pm 40$ & $(215 \pm 64)$ \\
\hline \multicolumn{7}{|c|}{ Weighted mean difference, ${ }^{3}$ mammal and charcoal (sample $7 / 7$ excluded) } & $771 \pm 29^{4}$ \\
\hline \multicolumn{8}{|c|}{ Marine Shell — Charcoal Comparisons } \\
\hline $2 / 3$ & AA23667 & mussel shell & $755 \pm 50$ & AA26528 & charcoal & $205 \pm 40$ & $550 \pm 64$ \\
\hline $3 / 5-6$ & AA23670 & mussel shell & $725 \pm 50$ & AA26530 & charcoal & $335 \pm 40$ & $390 \pm 64$ \\
\hline $4 / 6-7$ & AA23672 & mussel shell & $805 \pm 50$ & AA26532 & charcoal & $245 \pm 40$ & $560 \pm 64$ \\
\hline $7 / 7$ & AA23674 & mussel shell & $830 \pm 50$ & AA26535 & charcoal & $950 \pm 40$ & $(120 \pm 64)$ \\
\hline $9 / 5$ & AA23677 & mussel shell & $840 \pm 50$ & AA26536 & charcoal & $505 \pm 45$ & $335 \pm 67$ \\
\hline \multicolumn{7}{|c|}{ Mean difference, shell and charcoal (sample $7 / 7$ excluded) } & $459 \pm 32^{5}$ \\
\hline \multicolumn{8}{|c|}{ Marine Mammal - Marine Shell Comparisons } \\
\hline $2 / 3$ & AA26529 & walrus ivory & $965 \pm 50$ & AA23667 & mussel shell & $755 \pm 50$ & $210 \pm 71$ \\
\hline $3 / 5,6$ & AA26531 & walrus ivory & $1170 \pm 50$ & AA23670 & mussel shell & $725 \pm 50$ & $445 \pm 71$ \\
\hline $7 / 7$ & AA26534 & seal bone ${ }^{2}$ & $1165 \pm 50$ & AA23674 & mussel shell & $830 \pm 50$ & $335 \pm 71$ \\
\hline \multicolumn{7}{|c|}{ Mean difference, mammal bone and shell } & $330 \pm 41^{6}$ \\
\hline
\end{tabular}

${ }^{1}$ Standard error of the difference is calculated as the square root of the summed variances ( $\left.\mathrm{s}^{2}\right)$ of the two measurements, and standard error of mean difference is calculated as the reciprocal of the square root of the summed reciprocals of variances of the individual differences (Long and Rippeteau, 1974).

${ }^{2}$ Phocid sp.

${ }^{3}$ Weighted inversely by the magnitude of the variances.

${ }^{4}$ Probability of this spread in measurements of a single entity (with $7 / 7$ omitted) is only slightly below .75 ( $F=0.50 ; 4 / \infty$ d.f.).

${ }^{5}$ Probability of this spread in measurements of a single entity (with $7 / 7$ omitted) is between 0.05 and 0.025 ( $F=3.07 ; 3 / \infty$ d.f.).

${ }^{6}$ Probability of this spread in measurements of a single entity is between 0.05 and $0.1(\mathrm{~F}=2.74 ; 2 / \infty$ d.f. $)$.

\section{Lower Naknek River}

In 1998, one of us (Dumond) led the excavation of the site designated NAK008, located some $6 \mathrm{~km}$ above the mouth of the Naknek River on Bristol Bay and the Bering Sea. Two matched pairs of charcoal (presumably from local trees) and sea mammal bone (in both cases the sternum of white whale or beluga, Delphinapterus leucas) were dated, both from a single aboriginal semisubterranean house. One pair clearly associated with the basal house floor provided an age difference of about 800 years (Table 4).

The second pair was in superficial fill that appeared to be spoil shoveled into the house after abandonment, apparently from the house immediately adjacent to it. The entire deposit was covered by a visible deposit of volcanic ash resulting from the eruption that occurred in the vicinity of Mt. Katmai in 1912, which appeared at the base of the sod. Below that deposit there was no item of any kind to suggest that the superficial filling had postdated the arrival of Europeans in the region, and the house from which that fill had apparently proceeded was also excavated and found to be entirely free of evidence of European contact. The nominally "modern" determination on the charcoal was therefore something of a surprise, although it is well known that the period of about 250 years immediately preceding the ${ }^{14} \mathrm{C}$ baseline of 1950 was one in which fluctuations in atmospheric carbon-14 were so great as to render determinations from objects of that period of somewhat doubtful reliability. The paired determination on charcoal and whale bone, as indicated in Table 4, was about 760 years. One alternative would be to simply ignore that pair of determinations. On the other hand, the age determined on the whale bone suggests a difference of at least roughly the same magnitude as that indicated by the less questionable pair. For this reason, the conservative approach seemed to be to take that "modern" date as meaning what it said, and average the two determinations. We note that no significant change in final conclusions would have resulted had we chosen to eliminate that more questionable pair from consideration.

\section{Cape Prince of Wales}

From his excavations in 1998 and 1999 in sites located at the community of Wales, Roger K. Harritt made available to us bones of seals of resident species that were in apparent association with samples of non-marine materials that he had dated in the course of his research. In one case (site TEL026), this terrestrial sample was peaty material thought to be from sod blocks that had formed 
TABLE 4. Paired ${ }^{14} \mathrm{C}$ ages of marine materials and wood charcoal, Naknek River, Cape Prince of Wales, and Unalaska Island.

\begin{tabular}{|c|c|c|c|c|c|c|c|}
\hline & \multicolumn{3}{|c|}{ Sample 1} & \multicolumn{3}{|c|}{ Sample 2} & \multirow[b]{2}{*}{ Difference $^{1}$} \\
\hline & Laboratory Number & Material & Conventional Age & Laboratory Number & Material & Conventional Age & \\
\hline \multicolumn{8}{|c|}{ Naknek River NAK008 } \\
\hline & Beta-132224 & whale bone ${ }^{2}$ & $1040 \pm 74$ & Beta- 127837 & charcoal & $240 \pm 50$ & $800 \pm 64$ \\
\hline & Beta- 134828 & whale bone ${ }^{2}$ & $760 \pm 50$ & Beta-127838 & charcoal & "modern"3 & $760 \pm 75$ \\
\hline \multicolumn{7}{|c|}{ Weighted mean difference,${ }^{4}$ whale bone and charcoal } & $783 \pm 50$ \\
\hline \multicolumn{8}{|c|}{ Cape Prince of Wales } \\
\hline TEL026 & 6 Beta-134829 & seal bone ${ }^{5}$ & $1100 \pm 50$ & Beta-129590 & peat & $460 \pm 50$ & $640 \pm 71$ \\
\hline \multirow[t]{2}{*}{ TEL079 } & Beta-139113 & seal bone ${ }^{5}$ & $1220 \pm 40$ & Beta-138747 & grass & $500 \pm 60$ & $720 \pm 72^{6}$ \\
\hline & & & & Beta-138746 & peat & $680 \pm 60$ & $540 \pm 72^{6}$ \\
\hline \multicolumn{7}{|c|}{ Mean difference as accepted, seal bone and grass or peat } & $679 \pm 51$ \\
\hline \multicolumn{8}{|c|}{ Summer Bay, Unalaska Island UNL092 } \\
\hline & Beta-132226 & whale bone ${ }^{7}$ & $2480 \pm 70$ & Beta-121404 & charcoal & $1900 \pm 60^{8}$ & $580 \pm 92$ \\
\hline & & & & Beta-121402 & charcoal & $2050 \pm 60^{8}$ & $430 \pm 92$ \\
\hline
\end{tabular}

${ }^{1}$ Standard error of the difference is calculated as the square root of the summed variances of the two measurements, and standard error of mean difference is calculated as the reciprocal of the square root of the summed reciprocals of variances of the individual differences (Long and Rippeteau, 1974).

${ }^{2}$ Beluga (Delphinapterus leucas).

${ }^{3}$ Given as $101.3 \pm 0.7 \%$. The modern sample variance of " $0.7 \%$ " is estimated for present purposes at .07 of the approximate 80 years represented by each $1 \%$ change in radiocarbon age calculated by the standard 5568-year half-life, or 56 years.

${ }^{4}$ Weighted inversely by the magnitude of the variances.

${ }^{5}$ Phocid sp.

${ }^{6}$ Probability of this spread in measurements of a single entity is less than $0.025(\mathrm{t}=1.98)$.

${ }^{7}$ Species undetermined.

${ }^{8}$ Probability of this spread in measurements of a single entity is less than $0.04(t=1.76)$.

portions of the walls of aboriginal houses. In the second case (site TEL079), there were two comparative samples. One was of grass, interpreted as a covering for the floor on which the seal bone lay; the second was again of peaty material believed to have come from the house wall. Unfortunately for the present comparison, the two terrestrial samples from TEL079 are too far apart to be reconciled with one another-two measurements of a single value (i.e., a single true date) could be expected to manifest the spread of nearly 200 years less than $2.5 \%$ of the time. Under this circumstance, we declined to average the two from site TEL079.

On the other hand, the two separate differences obtainable from TEL079, of 720 and 540 years, are both near enough to the date of 640 years obtained from the pair from TEL026 that with it, either could reflect a single value (i.e., $\mathrm{t}=0.8$, or 1.0 ). Nevertheless, because the grass floor covering appears rather clearly to be contemporary with the use of the floor (and the seal bone), whereas the sod could conceivably be substantially older than the house constructed with or near it, the choice between these two favored the greater of the two differences. The differences of $640 \pm 71$ and 720 \pm 72 , therefore, are averaged in Table 4 .

\section{Unalaska Island}

In 1998, excavations were conducted at Summer Bay (site UNL092) by Richard A. Knecht of the Museum of the
Aleutians, as a result of an oil spill the previous winter. Partial remains of a whale, species undetermined, were encountered in the occupation layer, and a rib section was made available for the present analysis. The section was thought to be dated by either one of two ${ }^{14} \mathrm{C}$ determinations on charcoal (the wood presumably of drift origin), neither of which, however, was in direct association with the whale remains. The two determinations, at $1900 \pm 60$ and $2050 \pm 60$ radiocarbon years ago, are far enough apart that a spread of that magnitude between two measurements of the same value would be expected somewhat less than $4 \%$ of the time $(\mathrm{t}=1.76)$. Under the circumstances, it appeared inadvisable to average the two charcoal ages, although the excavation data do not appear to indicate which of the two to choose as more likely (R. Knecht, pers. comm. 1999). Somewhat ironically, however, the two differences-580 \pm 92 and $430 \pm 92$-are themselves close enough that a single underlying value could appear, as these do, more than $10 \%$ of the time $(t=1.15)$. Given the lack of agreement of the two basic ${ }^{14} \mathrm{C}$ determinations, however, we hesitate to make use of a mean $(505 \pm 65)$ in this case.

\section{CONCLUDING DISCUSSION}

A summary of results included in Tables 1 through 4 is presented in Table 5. The largest battery of results, of differences between 19 paired charcoal and sea mammal 
remains, contains values varied enough to suggest that attempts to understand a marine reservoir effect in the region are essentially hopeless. As noted in an earlier section, however, we believe it is appropriate to seek a limited number of underlying values as a further and desirable simplification of the data, and we also find that the results in at least the majority of these cases are coherent enough to reinforce this belief. Accordingly, we divided the charcoal vs. sea mammal pairs into two sections. The larger section, labeled Majority, includes six measurements or means of multiple measurements that represent a total of 14 pair-differences. It consists of means or measures that for the most part were supported by quantitative considerations set out in the preceding discussions. The second, labeled Residuals, includes the others.

With regard to the Majority, the two cases involving single pairs warrant further discussion. That included from the Hillside site on St. Lawrence Island is the larger of the two pair-differences from that site. As noted earlier, these two differences could not be averaged on statistical grounds. It was the larger of the two that appeared to find some support in the greater mean difference from the Gambell-area graves from St. Lawrence Island, as well as in other values listed in the same section of Table 5 .

Even more requiring of discussion was the choice of the greater of two conflicting differences from Summer Bay on Unalaska Island. The final decision in that case was based on the fit of the larger date with the remainder in the Majority group. That is, six values such as those of the Majority group represent a spread in measurements of a single entity that could be expected to occur $20 \%$ of the time. Inclusion of the mean of the two differences between those determinations and that from the whale fragment $(505 \pm 65)$, however, results in a spread that could be expected in six measurements less often than one time in $100(\mathrm{~F}=3.49)$. This result, with again the possibility that old driftwood yielded the older ${ }^{14} \mathrm{C}$ age, led to the single inclusion of the larger difference $(580 \pm 92)$ in the Majority group. It should be also be noted that eliminating it entirely would have little effect on the grand mean of the Majority group, causing it to rise only a few points.

In the Residual group, the considerations in two cases (the Hillside site and Unalaska Island) were that the difference values were too low to combine in a statistical sense with the Majority group. With regard to the graves from St. Lawrence Island, as well as the "older" charcoal from Unalaska, the question remains regarding the wood involved in the pairs. At the same time, it must be recognized that these values are close enough to warrant being averaged, and it is entirely possible that they represented another single value that pertains to the reservoir effect. Although the possibility of the existence of more than a single value for the reservoir effect in the Bering Sea certainly is one we seriously entertain, the result from the Majority group appears to be the more robust of the comparisons of charcoal versus sea mammal residues.
TABLE 5. Recapitulation of differences between paired ${ }^{14} \mathrm{C}$ ages, eastern Bering Sea region.

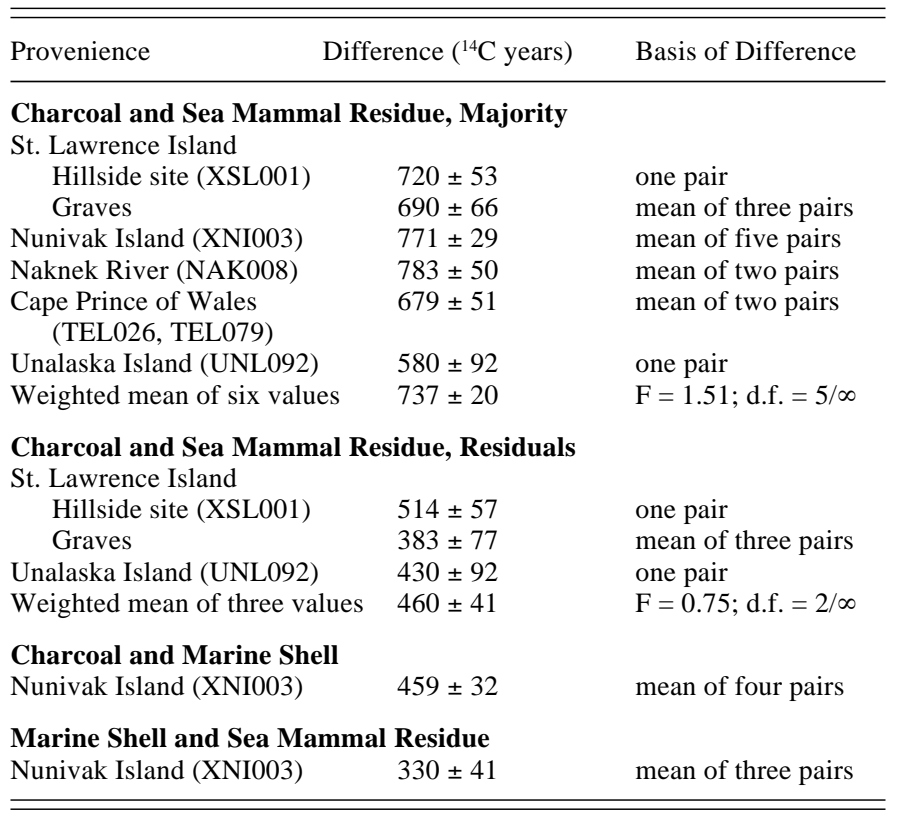

Note, however, that the weighted mean of the Residuals is almost exactly that of the mean of the charcoal and marine shell differences obtained from Nunivak Island, even though that particular mean, as noted in connection with Table 3, was from four pair-differences that slightly exceeded the confidence level that most researchers find to be the most comfortable (i.e., 5\%). The significance of this apparent agreement cannot now be fully assessed, but our discussion regarding conditions in the Bering Sea, below, bears directly on the subject.

The points we draw from the present analysis are these:

On the basis of radiocarbon determinations on 14 matched pairs of marine mammal residue and terrestrial products (charcoal, wood, or grass), the gross differences between results from these materials appear in most cases to exceed 700 radiocarbon years or, more specifically, somewhere (rounding slightly) around $735 \pm 20$ years.

Results from marine shell, although limited to only four pairs, suggest a significantly lesser value, one approximating $460 \pm 35$ years. This departure from the results regarding the majority of sea mammal residues is supported by differences among three marine shell-marine mammal pairs, at about $330 \pm 40$ years. We do not know whether 460 years is a reservoir effect on shell that would obtain in widespread areas of the Bering Sea or one that is local to Nunivak Island, but we have no reason to suppose it does not fairly reflect circumstances of the eastern Bering Sea.

Neither are we able to specify in a definitive way the cause of the differential we present between sea mammaland shell-derived ${ }^{14} \mathrm{C}$ determinations, although we presume, as we shall indicate, that this is related to sea mammals' feeding in areas more widely spread than those represented by the bivalves. The interplay of feeding behavior and the peculiar Bering Sea environment must 
also be related to a somewhat unexpected uniformity among the ${ }^{14} \mathrm{C}$ determinations from sea mammal remains that we have dealt with. That is, ocean depth is thought to be crucial to the magnitude of ${ }^{14} \mathrm{C}$ reservoir effect, whereas our present treatment has employed measurements from both benthic feeders (walrus and gray whale) and surface feeders (seals, bowhead and beluga whales) and found them to reflect little difference. We turn now to this topic.

The northern and eastern edges of the Bering Sea cover the Bering Platform, where depths are generally less, and often much less, than $130 \mathrm{~m}$. Waters of this depth, as noted earlier, would be considered "surficial" in terms of the modeled surface ${ }^{14} \mathrm{C}$ age curve of Stuiver and Braziunas (1993). Thus, if their definition describes the real as well as the modeled world, one would actually expect little difference in radiocarbon ingestion (and hence ${ }^{14} \mathrm{C}$ ages) between surface and bottom-feeding organisms confined to waters above the Platform.

To the south and west, however, the sea bottom drops rapidly, with depths in some areas exceeding $3000 \mathrm{~m}$. It is across some of these Bering Sea depths that currents pass northward between the western end of St. Lawrence Island and the southeastern tip of the Chukchi Peninsula of Asia-a major gateway through which, in the absence of contrary winds, flow more than $70 \%$ of the waters that pass into Bering Strait and the Chukchi Sea (Overland and Roach, 1987). Some of these deeper waters are known to upwell in the same gateway area, creating markedly colder surface temperatures on the western edge of the northern Bering Sea than on the eastern edge (Walsh et al., 1989). The eastern margin of the Sea partakes of comparatively little of this circulation, which is evidently especially the case around Nunivak Island (Overland and Roach, 1987), the source of a large body of our samples, including all of the mollusks measured.

Under this situation, our presumptions at this time are two. First, given the shallow depth of much of the Bering Sea, many of both bottom- and surface-feeding sea mammals partake of approximately the same carbon diet and so should yield approximately equal ages. Second, free-swimming species feeding toward the west, with its upwelling of deeper water, ingest more old carbon than is available to benthic organisms confined to the immediate eastern shoreline, as at Nunivak Island. From this, we hypothesize that shellfish measured from the immediate vicinity of either Cape Chaplin or western St. Lawrence Island would yield ages more closely approximating those of the majority of the sea mammals involved in the present sample. At the same time, it is also possible that wide-ranging animals, such as some whale species, would not date in the same way as those more nearly confined to the Bering Sea.

With this in view, we note again that results from five paired differences (Residuals) between sea-mammal and terrestrial-material determinations approximate those obtained between shell and charcoal. Although there appear to be reasons to regard each of the former five with some suspicion, it is nevertheless entirely possible that they represent another value for the marine reservoir effect in the Bering Sea. This value might possibly be dependent on feeding habits of marine animals that cannot now be assessed, although we must also grant the possibility that it is related to other species characteristics, of which we are unaware. In any event, given the geographic spread between the passes through which water enters the Bering Sea, the differences in depth within the Sea itself, and the resultant likelihood that surface waters of different areas are the results of upwelling from substantially different depths, we believe that variations in effective carbon "age" in the several areas of the sea are more expectable than surprising.

Finally, we recognize that there is presently enough uncertainty in measurement of the marine reservoir effect within the Bering Sea that some investigators may simply attempt to avoid all use of marine materials when in quest of ${ }^{14} \mathrm{C}$ ages accurate within less than several centuries. We are much less pessimistic than this, but it is certainly clear that baselines for the reservoir effect in the Bering Sea must be determined locally whenever radioactive carbon age measurements from marine products are sought. Nevertheless, the data here can be taken to indicate that in few cases will the effect be less than around 450 years. An effect in excess of 700 years may well be the dominant one, as we believe our more robust results demonstrate.

\section{ACKNOWLEDGEMENTS}

Griffin's excavations on Nunivak Island were supported by NSF award OPP-9629758, and Dumond's on the Naknek River, by NSF award OPP-9803814, both to the University of Oregon. Radiocarbon determinations for Nunivak were provided through NSF-Arizona AMS Facility, University of Arizona, Tucson, with additional financial support (for these and other dates) from the U.S. Fish and Wildlife Service (Anchorage) and the University of Oregon Foundation. We thank the Department of Anthropology, National Museum of Natural History, Smithsonian Institution, for permission to date samples from St. Lawrence Island; Roger K. Harritt, for datable samples from Cape Prince of Wales; Richard A. Knecht, for a whale bone sample from Unalaska Island; and Owen K. Mason, for a discussion of Bering Sea surface temperatures that led us to some of the references we cite. Three peer reviewers (anonymous and otherwise) provided thoughtful comments on an earlier draft, which we gratefully considered in our revision, acting on some but disagreeing with others-possibly to our detriment.

\section{REFERENCES}

BANDI, H.-G. 1984. Allgemeine Einführung und Gräberfunde bei Gambell am Nordwestkap der St. Lorenz Insel, Alaska. St. Lorenz Insel-Studien, Berner Beiträge zur archäologischen und ethnologischen Erforschung des Beringstrassengebietes. Vol 1. Bern: Verlag Paul Haupt. 
BOWMAN, S. 1990. Radiocarbon dating. Berkeley: University of California Press.

CLARK, R.M. 1975. A calibration curve for radiocarbon dates. Antiquity 49:251-266.

COLLINS, H.B., Jr. 1937. Archeology of St. Lawrence Island, Alaska. Smithsonian Miscellaneous Collections 96(1). Washington, D.C.: Smithsonian Institution.

DUMOND, D.E. 1998. The Hillside site, St. Lawrence Island, Alaska: An examination of collections from the 1930s. University of Oregon Anthropological Papers 55. Eugene, Oregon.

DYE, T. 1994. Apparent ages of marine shells: Implications for archaeological dating in Hawaii. Radiocarbon 36(1):51 -57.

DYKE, A.S., McNEELY, R.N., and HOOPER, J. 1996. Marine reservoir corrections for bowhead whale radiocarbon age determinations. Canadian Journal of Earth Sciences 33: $1628-1637$.

GRIFFIN, D.G. 1999. Portrait of Nash Harbor: Prehistory, history and lifeways of an Alaskan community. Ph.D. dissertation in Anthropology, University of Oregon, Eugene. Ann Arbor, Michigan: UMI Dissertation Services.

HUGHES, C.C. 1960. An Eskimo village in the modern world. Ithaca: Cornell University Press.

INGRAM, B.L., and SOUTHON, J.R. 1996. Reservoir ages in eastern Pacific coastal and estuarine waters. Radiocarbon 38(3):573-582.

KENNETT, D.J., INGRAM, B.L., ERLANDSON, J.M., and WALKER, P. 1997. Evidence for temporal fluctuations in marine radiocarbon reservoir ages in the Santa Barbara Channel, southern California. Journal of Archaeological Science 24: $1051-1059$.

KRUPNIK, I. 1993. Arctic adaptations. Hanover, New Hampshire: University Press of New England.

LONG, A., and RIPPETEAU, B. 1974. Testing contemporaneity and averaging radiocarbon dates. American Antiquity 39(2): $205-215$.
McGHEE, R.J., and TUCK, J. 1976. Un-dating the Canadian Arctic. In: Maxwell, M.S., ed. Eastern Arctic prehistory: Paleoeskimo problems. Memoirs of the Society for American Archaeology 31. 6-14.

OESCHGER, H., SIEGENTHALER, U., SCHOTTERER, U., and GUGELMANN, A. 1975. A box diffusion model to study the carbon dioxide exchange in nature. Tellas 27:168-192.

OVERLAND, J.E., and ROACH, A.T. 1987. Northward flow in the Bering and Chukchi Seas. Journal of Geophysical Research 92(C7):7097-7105.

RAINEY, F., and RALPH, E. 1959 Radiocarbon dating in the Arctic. American Antiquity 24(4):365-374.

ROBINSON, S.W., and THOMPSON, G. 1981. Radiocarbon corrections for marine shell dates with application to southern Pacific Northwest Coast prehistory. Syesis 14:45-57.

STUIVER, M., and BRAZIUNAS, T.F. 1993. Modeling atmospheric ${ }^{14} \mathrm{C}$ influences and ${ }^{14} \mathrm{C}$ ages of marine samples to $10,000 \mathrm{BC}$. Radiocarbon 35(1):137-189.

STUIVER, M., and REIMER, P.J. 1993. Extended ${ }^{14} \mathrm{C}$ data base and revised CALIB 3. ${ }^{14} \mathrm{C}$ age calibration program. Radiocarbon 35(1):215-230.

TAYLOR, R.E. 1987. Radiocarbon dating: An archaeological perspective. Orlando, Florida: Academic Press.

U.S.DEPARTMENT OFCOMMERCE. 1961. North Pacific Ocean: Climatological and oceanographic atlas for mariners. Vol. 2. Prepared by the Office of Climatology and the Oceanographic Analysis Division. Washington. D.C.: U.S. Government Printing Office.

WALSH, J.J., McROY, C.P., COACHMAN, L.K., GOERING, J.J., NIHOUL, J.J., WHITLEDGE, T.E., BLACKBURN, T.H., PARKER, P.L., WIRICK, C.D., SHUERT, P.G., GREBMEIER, J.M., SPRINGER, A.M., TRIPP, R.D., HANSELL, D.A., DIENIDI, S., DELEERSNUDER, E., HENRIKSEN, K., LUND, B.A., ANDERSEN, P., MÜLLER-KARGER, F.E., and DEAN, K. 1989. Carbon and nitrogen cycling within the Bering/Chukchi Seas. Progress in Oceanography 22:277-359. 